\title{
IDENTIFIKASI KARAKTER MORFOMETRIK SEBAGAI PENDUGA FEKUNDITAS IKAN PATIN JAMBAL (Pangasius djambal) FAKTOR KUNCI UNTUK SELEKSI
}

\author{
Sularto", Evi Tahapari"), dan Wartono Hadie" \\ *) Loka Riset Pemuliaan dan Teknologi Budidaya Perikanan Air Tawar \\ Jl. Raya Sukamandi No. 2, Subang 41256 \\ E-mail:sularto61@xl.blackberry.com \\ **) Pusat Penelitian dan Pengembangan Perikanan Budidaya \\ Jl. Ragunan 20, Pasar Minggu, Jakarta Selatan 12540
}

(Naskah diterima: 24 Mei 2010; Disetujui publikasi: 17 Januari 2011)

\begin{abstract}
ABSTRAK
Fekunditas merupakan salah satu karakter yang sangat penting dalam kegiatan budidaya ikan. Penelitian ini bertujuan untuk mencari karakter morfometrik penduga fekunditas pada ikan patin jambal sebagai dasar untuk melakukan seleksi. Ikan uji yang digunakan adalah ikan patin jambal generasi F1 sebanyak 45 ekor. Setiap induk diberi tanda (tag) dengan menggunakan microchip. Pengukuran karakter morfometrik meliputi panjang standar, panjang kepala, tinggi badan, dan luas rongga perut yang akan dijadikan karakter penduga fekunditas. Analisis data menggunakan program SAS dengan PROC REG. Hasil penelitian menunjukkan adanya indikasi korelasi positif $(\mathrm{P}<$ $0,01)$ antara karakter morfometrik pada panjang rongga perut, tinggi linea lateralis, dan luas rongga perut, dengan fekunditas $\left(r^{2}=0,7831\right)$. Oleh karena itu luas rongga perut ikan patin jambal dapat digunakan sebagai indeks untuk seleksi karakter fekunditas.
\end{abstract}

KATA KUNCl: luas rongga perut, morfometrik, fekunditas, Pangasius djambal

ABSTRACT: Identification of morphometrics character as a fecundity estimator for Indonesian catfish (Pangasius djambal): key to selection trait. By: Sularto, Evi Tahapari, and Wartono Hadie

Fecundity of fish is one of the principle characters that plays an important role in aquaculture. This research was aimed to find the main character related to the fecundity of Indonesian catfish as a basis in selective breeding. Fourty five female broodstock of Indonesian catfish Fl generation were used in this research. All of the fish were reared in a floating net cage of $6000 \mathrm{~m}^{2}$ placed in an earthen pond. The morphometric measurement used in this researh to assess the fecundity were body length, head length, body depth, and body cavity. The data was analyzed using SAS program with PROC REG. The reseach result showed that there were positive correlation indication $(P<0.01)$ between the wide of the body cavity and fecundity $r^{2}=0.7831$. Therefore, wide of body cavity could be used as an index of morphometric characterization for fecundity character selection.

KEYWORDS: abdominal wide, morphometric character, fecundity, Pangasius djambal 


\section{PENDAHULUAN}

Ikan patin jambal (Pangasius djambal) merupakan ikan patin asli Indonesia. Patin jambal merupakan komoditas ekspor karena memiliki daging putih yang sangat disukai pasar Jepang, Eropa, dan Amerika. Oleh karena itu, setelah ikan patin jambal berhasil dipijahkan pada tahun 1998 (Legendre et al., 1998) dan dikukuhkan oleh pemerintah sebagai ikan budidaya pada tahun 2000 yang mengakibatkan permintaan benih terus meningkat. Namun untuk memenuhi kebutuhan benih secara massal masih menghadapi kendala. Hal tersebut disebabkan karena patin jambal fekunditasnya rendah, sehingga menghasilkan benih sedikit. Legendre et al. (2001) melaporkan bahwa fekunditas ikan patin jambal berkisar 1.100-23.000 butir per kilogram induk betina. Dari data tersebut menunjukkan adanya variasi fekunditas yang lebar antar individu, sehingga dapat memberi gambaran adanya peluang untuk dilakukan seleksi. Hal ini dapat dipahami patin jambal merupakan komoditas budidaya yang masih baru. Sampai saat ini belum banyak bahkan belum ada upaya perbaikan mutu genetik patin jambal tentang fekunditasnya.

Menurut Effendi (1979), fekunditas ialah jumlah telur masak sebelum dikeluarkan pada waktu memijah. Sedangkan fekunditas nisbi yaitu jumlah telur per satuan bobot atau panjang ikan (Nikolsky, 1963). Dalam penelitian ini fekunditas yang dimaksud adalah jumlah telur yang dapat diovulasikan per siklus induk matang gonad setelah mendapatkan rangsangan hormon.

Untuk mendapatkan induk yang memiliki fekunditas tinggi salah satu alternatif yang dapat dilakukan dengan menerapkan program seleksi. Untuk melakukan seleksi berdasarkan fekunditas perlu dicari karakter penduga yang berkorelasi positif.

Tujuan penelitian ini adalah mendapatkan informasi mengenai hubungan antara karakter morfometrik dengan fekunditas ikan patin jambal.

\section{BAHAN DAN METODE}

Hewan uji yang digunakan pada penelitian ini adalah induk ikan jambal F1. Jumlah induk yang digunakan adalah: induk betina 45 ekor. Semua induk yang digunakan diberi tanda (tag) dengan menggunakan micro chip yang dapat dibaca dengan tag reader.
Pemeliharaan induk dilakukan di kolam percobaan Loka Riset Pemuliaan dan Teknologi Budidaya Perikanan Air Tawar (LRPTBPAT), Sukamandi. Wadah pemeliharaan adalah jaring berukuran $7 \mathrm{~m} \times 7 \mathrm{~m} \times 2 \mathrm{~m}$ yang diletakkan dalam kolam tanah berukuran $6.000 \mathrm{~m}^{2}$ dengan kedalaman air 1,25-1,50 m. Agar diperoleh pertumbuhan yang baik, kondisi oksigen diupayakan $>3 \mathrm{mg} / \mathrm{L}$. Untuk mempertahankan kondisi tersebut dilakukan dengan pemberian aerasi terutama pada malam hari. Pakan yang diberikan berupa pelet komersial dengan kadar protein $28 \%$ sebanyak $2 \%$ bobot biomassa per hari. Pengamatan dilakukan setiap 2 bulan.

Parameter yang diamati meliputi: karakter morfometrik, bobot badan, perkembangan gonad, dan fekunditas. Karakter morfometrik yang diukur: panjang standar, tinggi LL depan, tinggi LL belakang, panjang rongga perut, luas rongga perut, bobot badan, panjang badan, panjang kepala, tinggi badan, dan lingkar badan. Untuk pengamatan perkembangan gonad dilakukan dengan cara mengamati sel telur (oosit) dengan teknik kanulasi, selain itu diukur juga fekunditas dan fekunditas relatif $/ \mathrm{kg}$.

Telur sebanyak 850 butir diamati di bawah mikroskop dengan perbesaran 25 kali yang dilengkapi dengan mikrometer. Data diameter oosit dicatat sehingga menghasilnya distribusi frekuensi. Dari distribusi frekuensi tersebut akan terlihat diameter oosit dengan frekuensi tertinggi (modus) yang dapat dijadikan dasar kematangan gonad. Rangsangan ovulasi menggunakan hormon HCG dan LHRH (Ovaprim). Total telur yang dapat terovulasikan digunakan sebagai standar parameter fekunditas. Parameter penunjang adalah data klimatologi yaitu musim dan kualitas air.

Analisis data dengan menggunakan uji regresi linier bivariate (PROC REG, SPEARMAN'S RHO, SAS, 1997) antara parameter morfometrik serta bobot dengan data fekunditas relatif. Hubungan antar variabel juga diuji menggunakan regresi linear dengan Program SPSS. Nilai korelasi ini digunakan sebagai standar untuk memprediksi fekunditas individu.

\section{HASIL DAN BAHASAN}

Data hasil pengamatan morfometrik, bobot badan, dan fekunditas dapat dilihat pada Tabel 1. Fekunditas diamati pada saat ovulasi dengan menghitung telur yang dihasilkan melalui striping. 


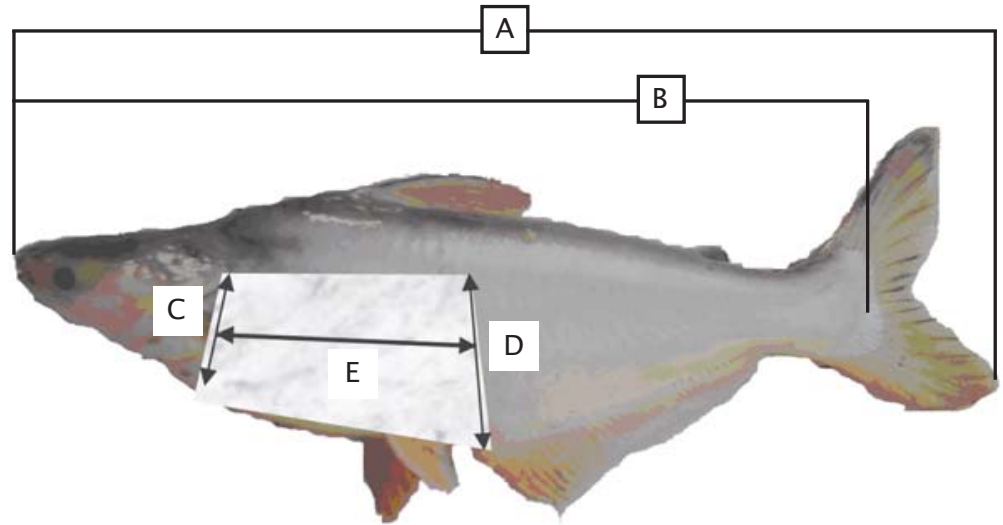

Gambar 1. Cara pengukuran karakter morfometrik. A. panjang total; B. panjang standar; C. tinggi perut depan hingga LL; D. tinggi perut belakang hingga LL; E. panjang rongga perut

Figure 1. Measurement of morphometric character. A. total length; $B$. standart length; $C$. height of front stomach to $L L ; D$. height of backside stomach to LL; E. length of celiac

Berdasarkan hasil uji statistik hubungan antara fekunditas dengan karakter morfometrik (panjang rongga perut, tinggi linea lateralis, dan luas rongga perut) serta bobot badan mempunyai korelasi positif $(\mathrm{P}<0,01)$ dengan nilai $\mathbf{r}^{2}=\mathbf{0 , 7 8 3 1}$. Hal ini berarti semakin luas rongga perut akan semakin tinggi fekunditasnya. Musa \& Bhuyian (2007) melaporkan bahwa fekunditas ikan Mystus nemurus Blkr berkorelasi dengan panjang total, panjang standar, tinggi badan, dan total bobot.

Untuk melihat hubungan masing-masing karakter morfometrik terhadap fekunitas dapat dilihat pada Gambar 2 sampai 5. Dari hasil analisis regresi antara parameter morfometrik dengan fekunditas memperlihatkan persamaan positif yang menunjukkan adanya hubungan positif antara pertambahan parameter morfometrik dengan pertambahan fekunditas.

Dari grafik terlihat adanya korelasi positif antara fekunditas dengan karakter morfometrik berupa panjang rongga perut, tinggi linea lateralis, dan luas rongga perut yang ditunjukkan dari persamaan garis Gambar la sampai $5 \mathrm{~b}$. Garis persamaan yang diperoleh menunjukkan adanya hubungan positif antara parameter morfometrik dengan fekunditas. Dari hasil analisis tersebut menunjukkan adanya indikasi korelasi antara panjang rongga perut, tinggi linea lateralis (jarak antara dasar perut sampai linea lateralis), dan luas rongga perut dengan fekunditas. Musa \& Bhuyian
(2007) melaporkan bahwa jumlah telur meningkat dengan meningkatnya bobot, panjang tubuh, bobot gonad, dan panjang gonad. Hasil yang sama juga dilaporkan pada ikan yang berbeda (Shafi \& Quddus, 1974; Doha \& Hye, 1970). Namun Musa \& Bhuyian (2007) juga melaporkan bahwa ditemukan beberapa ikan dengan ukuran sama mempunyai fekunditas yang berbeda. Dilaporkan pula oleh Bagenal et al. (1957) bahwa faktor lingkungan dan pakan berpengaruh terhadap fekunditas. Fekunditas patin jambal juga berkorelasi positif dengan bobot, hal ini dapat dipahami bahwa semakin berat bobot badan semakin tinggi nilai ovosomatik indeksnya yang berbanding lurus dengan fekunditasnya.

Hal ini berlaku baik pada fekunditas sebenarnya maupun fekunditas relatifnya. Namun demikian keeratan hubungan antara parameter morfometrik dengan fekunditasnya dapat dilihat pada Tabel 2.

Hasil perhitungan koefisien korelasi $\left(r^{2}\right)$ antara parameter morfometrik dengan fekunditas memperlihatkan hubungan yang positif. Sujana (1992) menjelaskan bahwa hubungan yang dinyatakan dengan koefisien korelasi tersebut tidak menunjukkan hubungan kausalita. Artinya satu parameter tidak menyebabkan parameter lain menjadi ada. Maksudnya adalah bahwa bukan semata-mata luasnya rongga perut yang menyebabkan fekunditas meningkat. Namun demikian ada 


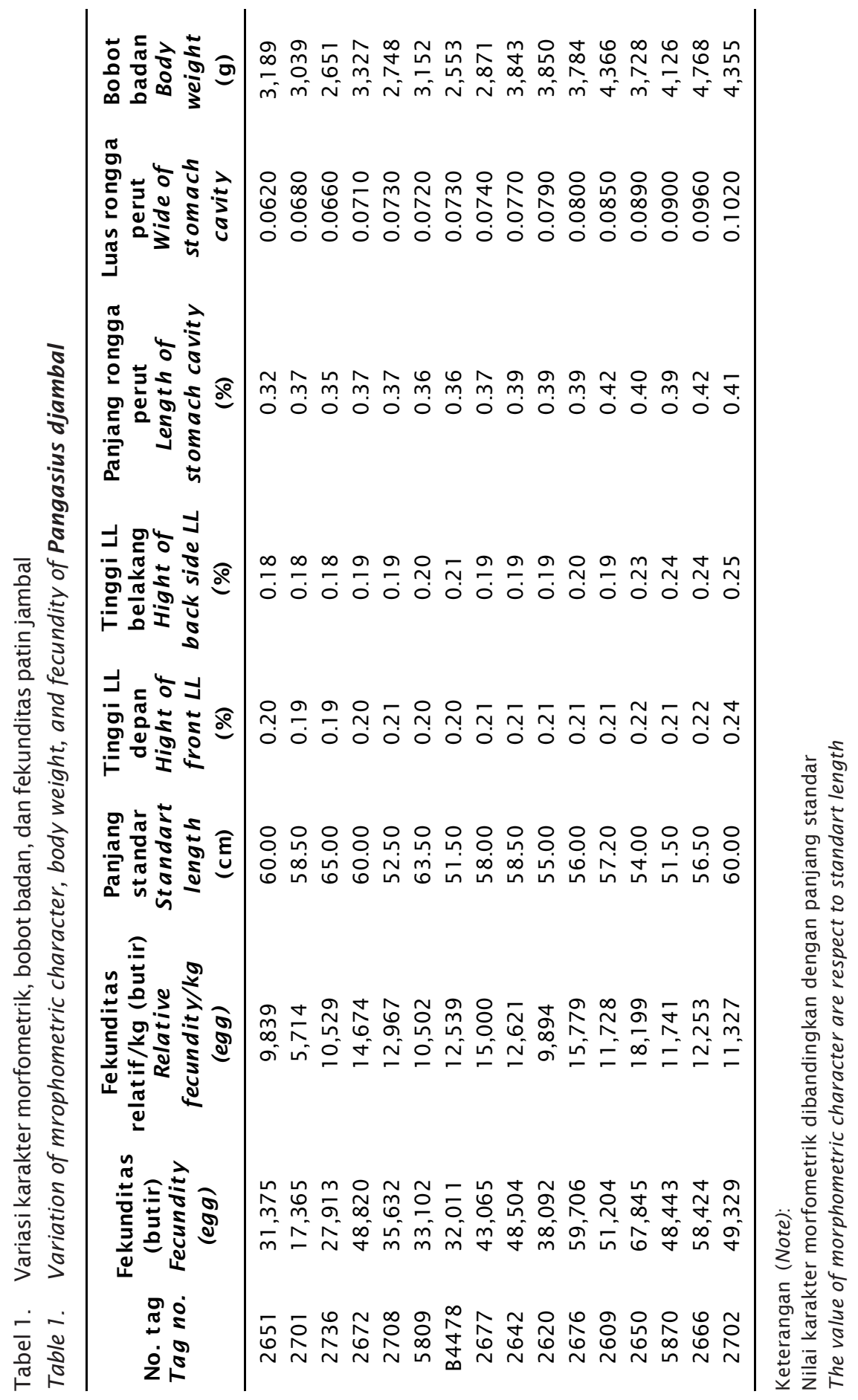




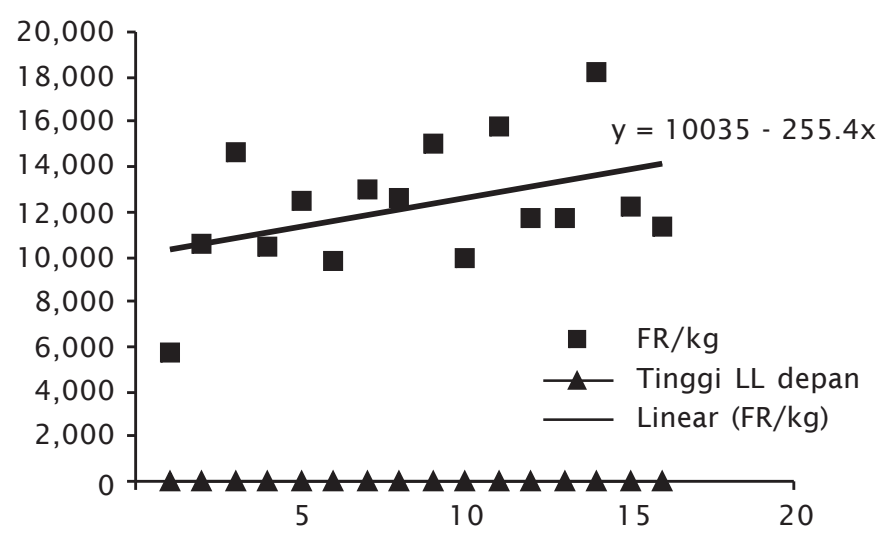

Gambar 1a. Hubungan antara tinggi LL depan dengan fekunditas

Figure 1a. Relationship between depth of front $L L$ with fecundity

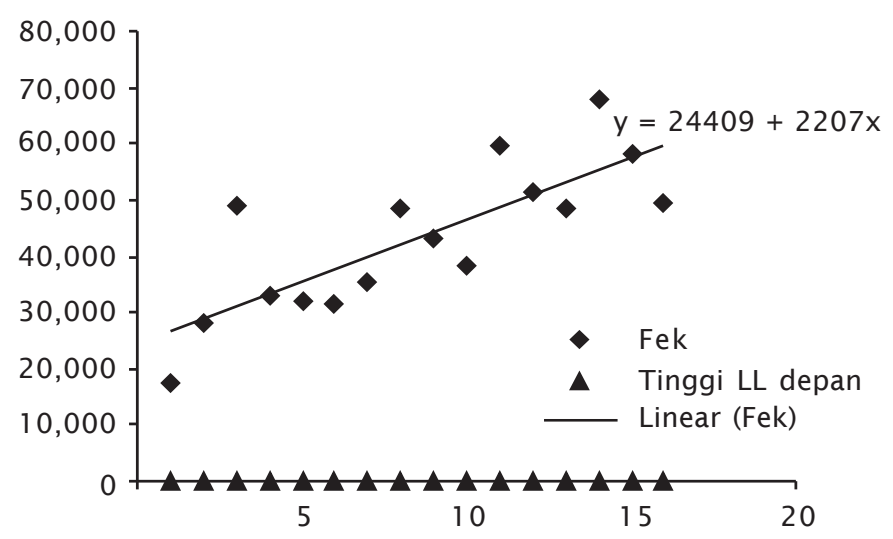

Gambar 1b. Hubungan antara tinggi LL belakang dengan fekunditas relatif Figure $1 b$. Relationship between depth of front $L L$ with relative fecundity

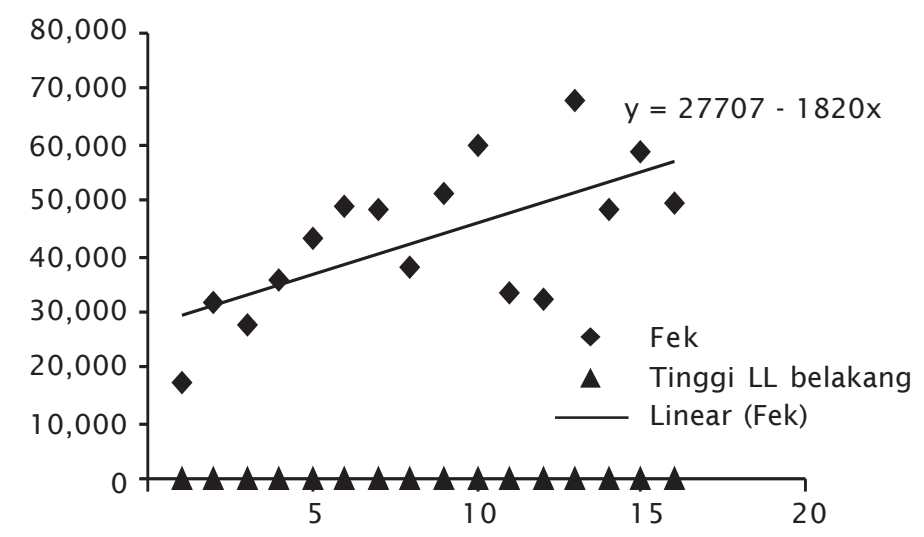

Gambar 2a. Hubungan antara tinggi LL belakang dengan fekunditas

Figure $2 a$. Relationship between depth of back $L L$ with fecundity 


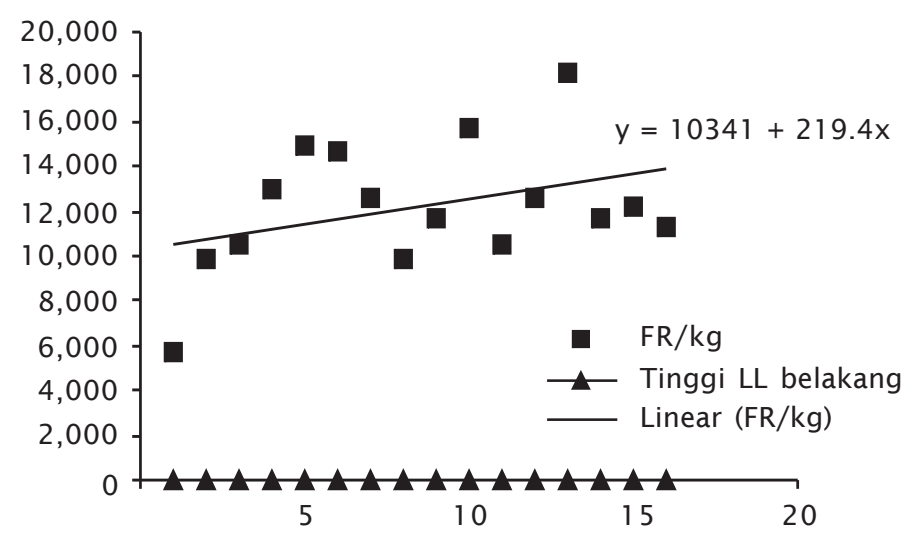

Gambar 2b. Hubungan antara tinggi LL belakang dengan fekunditas relatif Figure $2 b$. Relationship between depth of back $L L$ with relative fecundity

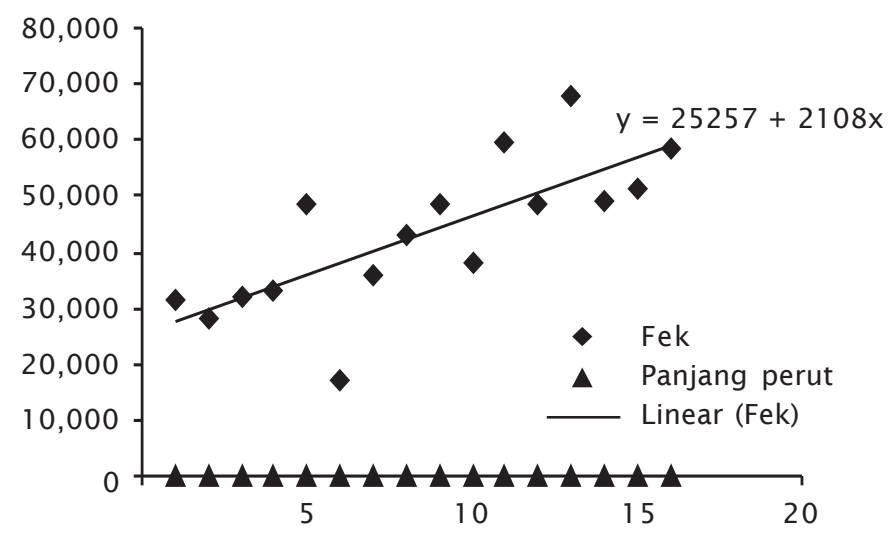

Gambar 3a. Hubungan antara panjang rongga perut dengan fekunditas

Figure 3a. Relationship between length of stomach cavity with fecundity

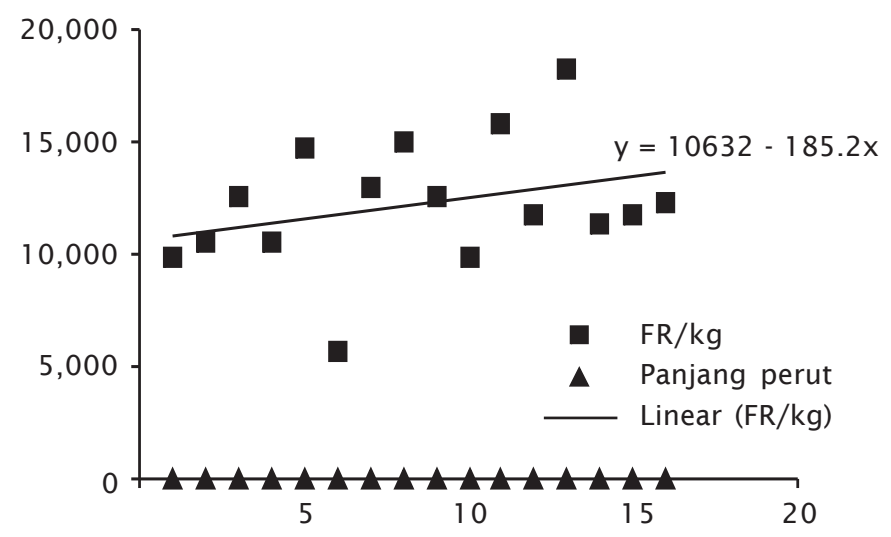

Gambar 3b. Hubungan antara panjang rongga perut dengan fekunditas relatif Figure $3 b$. Relationship between length of stomach cavity with relative fecundity 


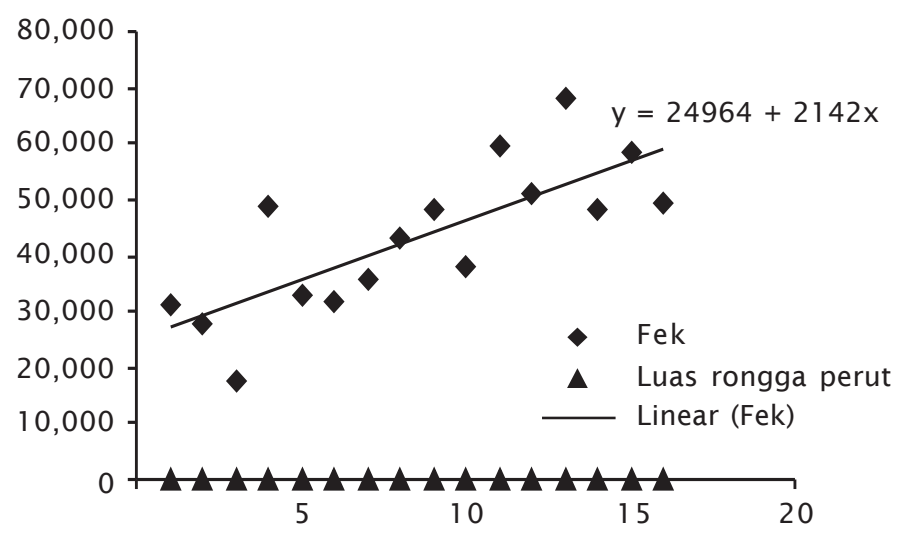

Gambar 4a. Hubungan antara luas rongga perut dengan fekunditas

Figure $4 a$. Relationship between wide of stomach cavity with relative fecundity

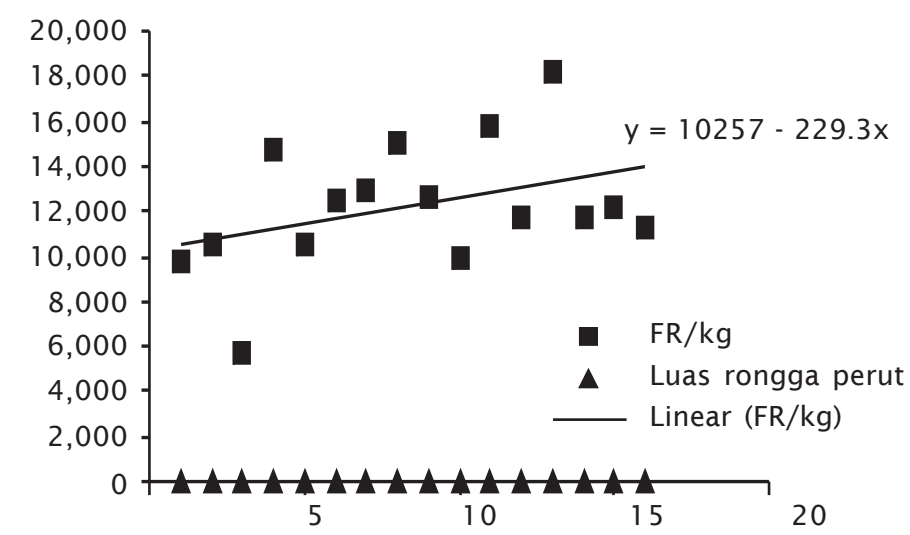

Gambar 4b. Hubungan antara luas rongga perut dengan fekunditas relatif

Figure $4 b$. Relationship between wide of stomach cavity with relative fecundity

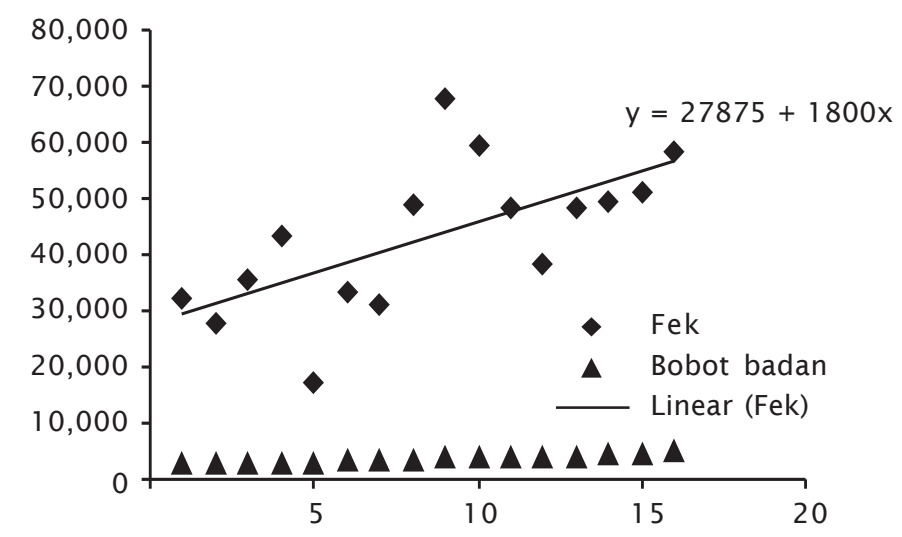

Gambar 5a. Hubungan antara bobot badan dengan fekunditas

Figure 5a. Relationship between body weight and fecundity 


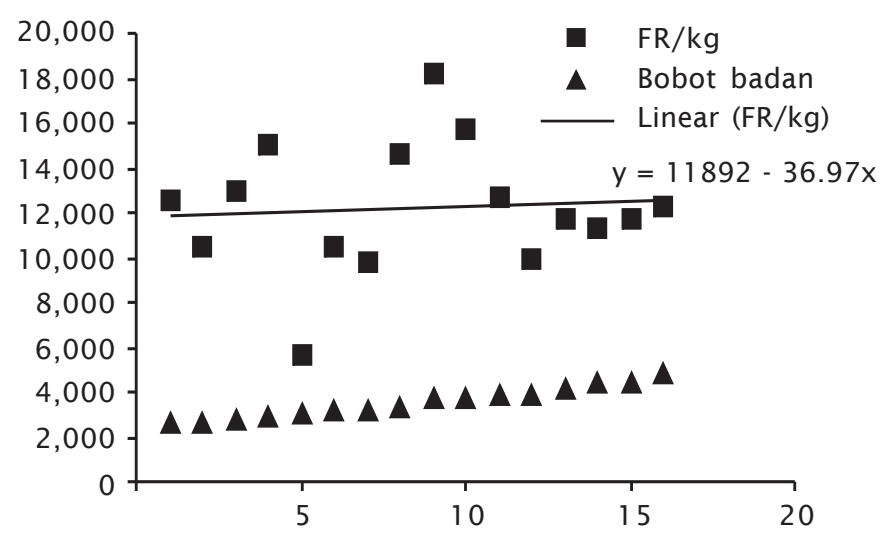

Gambar 5b. Hubungan antara bobot badan dengan fekunditas relatif

Figure 5b. Relationship between body weight and relative fecundity

hubungan yang positif antara meningkatnya luas rongga perut dengan tingginya fekunditas pada ikan patin jambal.

Semakin tinggi nilai koefisien korelasi, berarti ada hubungan yang dekat antara rongga perut atau parameter lainnya dengan fekunditas. Atau dengan kata lain dapat dikatakan bahwa meningkatnya luasan rongga perut memungkinkan meningkatnya fekunditas.

Parameter yang memiliki koefisien korelasi tinggi terhadap fekunditas $(>0,5)$ seperti LL bagian depan, panjang rongga perut, dan luas rongga perut berarti memiliki hubungan yang erat dengan meningkatnya fekunditas. Parameter tersebut memungkinkan ukuran ovarium berkembang secara maksimal dan memungkinkan jumlah telur lebih banyak. Hubungan antara parameter morfometrik terhadap fekunditas relatif rendah $\left(r^{2}<0,2\right)$. fekunditas relatif adalah jumlah telur yang diovulasikan per satuan bobot ikan. Koefisien korelasi antara bobot badan dan korelasi sangat rendah $\left(r^{2}=0,003\right)$, artinya bahwa tidak terdapat hubungan yang bermakna antara peningkatan bobot badan induk dengan peningkatan fekunditas.

Tabel 2. Hasil penghitungan koefisien regresi $\left(r^{2}\right)$ antara parameter morfometrik terhadap fekunditas ikan patin

Table 2. The value of coeficient regression $\left(r^{2}\right)$ between morphometric parameters and the fecudity of catfish

\begin{tabular}{lcc}
\hline \multicolumn{1}{c}{\begin{tabular}{c}
\multicolumn{1}{c}{ Paramet er morfomet rik } \\
Morphomet ric paramet er
\end{tabular}} & $\begin{array}{c}\text { Fekunditas } \\
\text { Fecundity }\end{array}$ & $\begin{array}{c}\text { Fekunditas relat if } \\
\text { Relat ive fecundity }\end{array}$ \\
\hline $\begin{array}{l}\text { Tinggi linea late ralis bagian belakang } \\
\text { Height of backside linea lateralis (TLLB) }\end{array}$ & 0.4247 & 0.1326 \\
$\begin{array}{l}\text { Tinggi linea late ralis bagian depan } \\
\text { Height of linea lateralis frontside (TLLD) } \\
\text { Panjang rongga perut } \\
\text { Length of celiac (PRP) } \\
\text { Luas rongga perut } \\
\text { Wide of celiac (LRP) }\end{array}$ & 0.625 & 0.1997 \\
$\begin{array}{l}\text { Bobot badan } \\
\text { Body weight (BB) }\end{array}$ & 0.5698 & 0.0945 \\
\hline
\end{tabular}


Oleh karena itu, parameter yang dapat digunakan untuk menduga fekunditas pada ikan patin jambal adalah LL bagian depan, panjang rongga perut, dan luas rongga perut. Sedangkan parameter bobot badan pada induk ikan jambal, bukan merupakan parameter penentu untuk pemilihan calon induk dengan fekunditas tinggi.

Dari hasil pengamatan selama penelitian, ikan patin jambal matang gonad sepanjang tahun. Meskipun demikian tingkat matang gonad tertinggi terjadi pada musim penghujan, demikian pula fekunditas tertinggi juga terjadi pada musim penghujan. Menurut Murua et al. (2003), penelitian mengenai reproduksi termasuk didalamnya pendugaan ukuran matang gonad, fekunditas, lamanya musim reproduksi, fraksi pemijahan, keberhasilan kapasitas reproduksi dari individu ikan. Sedangkan Witthames et al. (1987) dalam Murua et al. (2003) di dalam suatu spesies ikan, fekunditas bervariasi sebagai hasil dari perbedaan adaptasi terhadap lingkungan. Fekunditas ikan patin jambal jauh lebih rendah (5.714-15.779 butir/kg) dibanding dengan patin siam yang dapat mencapai 300.000 butir/ kg. Hal ini disebabkan ukuran telur yang lebih besar, juga nilai ovosomatik yang rendah (<10\%), sedangkan patin siam nilai ovosomatik indeks mencapai 20\%-30\% terutama pada musim penghujan. Berdasarkan pengamatan ternyata induk ikan patin jambal kurang responsif terhadap pakan yang diberikan, sehingga tidak ditemukan induk yang matang gonad secara maksimal. Hal tersebut diduga karena faktor adaptasi atau domestikasi ikan patin jambal yang masih relatif baru dalam lingkungan budidaya.

Selama penelitian berlangsung, kualitas air (Tabel 3) diamati untuk memastikan kondisi induk dalam lingkungan yang optimal.

Kualitas air selama penelitian mengalami fluktuasi terutama kandungan oksigen terlarut (DO) dan $\mathrm{CO}_{2}$. Kandungan oksigen terendah pada pagi hari sekitar pukul 05.00 yaitu 1,08 $\mathrm{mg} / \mathrm{L}$ dan tertinggi pada siang hari sekitar pukul 15.30 yaitu mencapai $8,80 \mathrm{mg} / \mathrm{L}$. Sedangkan kandungan $\mathrm{CO}_{2}$ berbanding terbalik dengan kandungan oksigen terlarut, kandungan $\mathrm{CO}_{2}$ tertinggi pada pagi hari sekitar pukul 05.00 yaitu mencapai $9,99 \mathrm{mg} / \mathrm{L}$ dan terendah pada siang hari pukul 15.30 yaitu $0,00 \mathrm{mg} / \mathrm{L}$ (tidak terdeteksi). Fluktuasi tersebut disebabkan aktivitas organisme yang ada di dalam kolam. Pada malam hari terjadi
Tabel 3. Kisaran kualitas air kolam pemeliharaan induk selama penelitian berlangsung

Table 3. Range of water quality in broodstock pond during the research period

\begin{tabular}{lc}
\hline \multicolumn{1}{c}{ Parameter } & Nilai (Value) \\
\hline $\mathrm{pH}$ & $7.15-8.24$ \\
Suhu (Temperature) $\left({ }^{\circ} \mathrm{C}\right)$ & $28.80-33.60$ \\
$\mathrm{DO}(\mathrm{mg} / \mathrm{L})$ & $1.08-8.80$ \\
Amoniak $($ Ammonia $)(\mathrm{mg} / \mathrm{L})$ & $0.045-0.35$ \\
Nitrit $($ Nitrite $)(\mathrm{mg} / \mathrm{L})$ & $0.036-0.85$ \\
Nitrat $($ Nitrate $)(\mathrm{mg} / \mathrm{L})$ & $0.05-0.11$ \\
$\mathrm{CO}_{2}(\mathrm{mg} / \mathrm{L})$ & $0.00-9.99$ \\
\hline
\end{tabular}

proses respirasi tanpa adanya proses fotosintesis, sehingga kandungan oksigen terlarut menurun dan sebaliknya kadar $\mathrm{CO}_{2}$ meningkat.

Dalam penelitian ini, untuk meningkatkan kandungan oksigen terlarut dilakukan dengan pemberian aerasi menggunakan pompa air. Namun untuk menciptakan kondisi yang ideal untuk pemeliharaan induk perlu upaya untuk meningkatkan kandungan oksigen terlarut minimal $3 \mathrm{mg} / \mathrm{L}$ serta menurunkan kandungan $\mathrm{CO}_{2}$. Karena peningkatan kandungan $\mathrm{CO}_{2}$ tanpa diimbangi peningkatan kandungan $\mathrm{O}_{2}$ akan mengganggu proses respirasi. Meskipun demikian kondisi air selama penelitian belum membahayakan terhadap sintasan induk patin jambal. Berdasarkan pengamatan selama penelitian tidak ada kematian induk akibat kekurangan oksigen atau tidak ada gejala kesulitan respirasi pada pagi hari. Slembrouck et al. (2005) melaporkan bahwa induk patin jambal dapat tahan hidup pada kondisi kandungan oksigen di bawah $1 \mathrm{mg} / \mathrm{L}$.

Kandungan amonia, nitrit, dan nitrat dalam kondisi yang layak dan aman untuk kehidupan ikan. Suhu air tertinggi terjadi pada bulan Juli sampai September, di mana pada siang hari mencapai $33,8^{\circ} \mathrm{C}$. Pada kondisi ini ikan kurang merespon terhadap pakan yang diberikan, sehingga pemberian pakan lebih banyak dilakukan pada malam hari.

Dari hasil pengamatan selama penelitian ternyata faktor kualitas air atau faktor musim sangat besar pengaruhnya terhadap perkembangan gonad ikan patin jambal. Persentasi induk yang matang gonad pada 
musim penghujan jauh lebih tinggi dibanding pada musim kemarau, hal ini disebabkan pada musim penghujan terdapat rangsangan lingkungan seperti timbulnya petrichor yang berpengaruh terhadap perkembangan gonad.

\section{KESIMPULAN}

Terdapat hubungan yang positif antara ukuran morfometrik dengan fekunditas ikan jambal. Ukuran LL bagian depan perut, panjang rongga perut, dan luas rongga perut yang mengindikasikan volume rongga perut yang luas juga mengindikasikan meningkatnya fekunditas secara seimbang dengan nilai $\mathbf{r}^{2}=$ 0,7831 . Ukuran morfometrik LL bagian depan, panjang rongga perut, dan luas rongga perut yang besar dapat digunakan untuk indikator fekunditas yang tinggi pada ikan patin jambal.

\section{DAFTAR ACUAN}

Doha, S. \& Hye, M.A. 1970. Fecundity of the Padma river (Hilsa ilisha). Pak. J. Scie., 22: 176-183.

Kinneen, S. 2003. Opportunistic sampling to estimate fecundity of chum and coho salmon from Norton Sound.Norton Sound Economic Development Corporation, LGL Alaska Research Associates, Inc., Anchorage, AK.

Komarudin, O. 2000. Ikan patin jambal andalan Indonesia. Warta Penelitian dan Pengembangan Pertanian, 22(3): 1-2.

Legendre, M., Slembrouck, J., \& Subagja, J. 1998. First Result on Growth and Artificial Propagation of Pangasius djambal in Indoensia. In the Biological Diversity and Aaquaculture of Clariid and Panasius Catfishes in South East Asia. Proceeding of the Midterm Workshop of the "Catfish Asia Project" Cantho, Vietnam, 11-15 May 1998.

Legendre, M., Pouyaud L., Slembrouck, J., Gustiano, R., Kristanto, A.H., Subagja, J., Komarudin, O., Sudarto, \& Maskur. 2000. Pangasius djambal: A new candidate species for fish culture in Indonesia Agricul- tural Research and Development Journal. Agency for Agricultural Research and Development. Ministry of Agriculture, 22(1): $14 \mathrm{pp}$.

Legendre, M., Subagja, J., Day, D., Sularto, \& Slembrouck, J. 2001 . Perkembangan Musiman Kematangan Gonad dan Pemijahan Buatan Ikan Pangasius djambal dan Pangasius nasutus dalam Program Penelitian Untuk Pengembangan Budidaya Ikan Patin Lokal (Siluriformes, Pangasiidae) di Indonesia. Laporan Departemen Luar Negeri, Kedutaan Perancis di Indonesia.

Lenormand, S., Slembrouck, J., Pouyaud, L., Subagja, J., \& Legendre, M. 1998. Evaluation of Hibridisation in Five Clarias Species (Siluriformes, Claridae) of African ( $C$. gariepinus) and Asian Origin (C. batrachus, C. meladerma, C. nieuhofii, and $C$. teijsmanni). In: Legendre, M. and A. Parisele. The Biological Diversity and Aquaculture of Clariid and Pangasiid Cathfishes in South-East Asia. Proceeding of The Mid-Term Workshop of The "Cathfish Asia Project". Cantho, Vietnam, 11-15 Mei 1998, p. 195-209.

Murua, H., Kraus, S., Saboride_Rey, F., Withames, P.R., Thorsen, A., \& Junguera, S. 2003. Precedurs to Estimate Fecundity of Marine Fish Spesies in Relation Their Reproductive Strategy. J. Northw. Art.Fish.Sci., 33: 33-54.

Musa, A.S.M. \& Bhuiyan, A.S. 2007. Fecundity on Mystus bleekeri (Day, 1877) from the River Padma Near Rajshahi City. Turkish Journal of Fisheries and Aquatic Sciences, 7: 161-162. SHORT PAPER.

Shafi, M. \& Quddus, M.M.A. 1974. The fecundity of the Common punti (Puntius stigma). Bangladesh J. Zoo., 2(2): 133-144.

Slembrouck, J., Komarudin, O., Maskur, \& Legendre, M. 2005. Technical Manual For Artificial Propagation of The Indonesian Catfish, Pangasius djambal. IRD-PRPB. Karya Pratama, Jakarta, 143 pp. 